\title{
PENDEKATAN MODEL LEVINE DALAM MENGATASI GANGGUAN TIDUR ANAK KANKER DI RSUPN DR CIPTO MANGUNKUSUMO JAKARTA
}

\author{
Rokhaidah $^{1 *}$, Allenidekania $^{2}$, Happy Hayati ${ }^{2}$ \\ 1. Program Studi Magister Fakultas Ilmu Keperawatan Universitas Indonesia, Depok 16424, Indonesia \\ 2. Fakultas Ilmu Keperawatan Universitas Indonesia, Depok 16424, Indonesia \\ *E-mail: rokhaidah@yahoo.com
}

\begin{abstract}
Abstrak
Anak dan remaja yang menderita kanker sering mengalami gangguan tidur yang dapat menyebabkan penurunan daya tahan tubuh dan memengaruhi kualitas hidup. Tujuan penulisan artikel ini adalah untuk memberikan gambaran penerapan Model Konservasi Levine dalam asuhan keperawatan pada anak dengan kanker yang mengalami gangguan tidur. Desain yang digunakan adalah studi kasus. Terdapat lima kasus yang menjadi pembahasan dalam artikel ini dan teridentifikasi bahwa masalah tidur merupakan masalah yang utama. Intervensi keperawatan yang diberikan didasarkan pada prinsip-prinsip konservasi yaitu konservasi energi, integritas struktural, integritas personal dan integritas sosial. Hasil evaluasi berdasarkan respon organismik menunjukkan sebagian besar masalah dapat teratasi dan menunjukkan perbaikan meskipun belum teratasi secara keseluruhan. Model Konservasi Levine direkomendasikan untuk dapat diterapkan dalam memberikan asuhan keperawatan pada anak dengan kanker yang mengalami gangguan tidur dengan intervensi sleep hygiene dan terapi komplementer pemberian madu sebelum anak tidur untuk mencapai hasil asuhan yang optimal.
\end{abstract}

Kata kunci: anak, gangguan tidur, kanker, model konservasi Levine

\begin{abstract}
Levine's Model Approach to Overcome the Sleeping Disturbance in Children with Cancer in Cipto Mangunkusumo Hospital Jakarta. Children and adolescents with cancer often experience sleep disorders that may lead to a decrease in the immune system and affect the quality of life. The purpose of this report is to provide an overview of Levine's Conservation Model application on nursing care of children with cancer experiencing sleep pattern disturbance. There are five cases which being discussed on this article and we found sleep disturbance as the main problem. Nursing interventions based on conservation principles such as energy conservation, structural integrity, personal integrity and social integrity were given. The evaluation of the intervention which based on organismic responses indicated that some problems were resolved, while some others were partially resolved with some improvement or unresolved. We recommend the application of Levine's Conservation Model on nursing care of children with cancer experiencing sleep disorders with the intervention of sleep hygiene and complementary therapies using honey before the children go to sleep to achieve optimal results.
\end{abstract}

Keywords: children, cancer, Levine's Conservation Model, sleeping problems

\section{Pendahuluan}

Kanker adalah pertumbuhan dan pembelahan sel dalam tubuh yang tidak terkendali, sel terus membelah dan membentuk sel baru yang abnormal yang dapat menyerang jaringan di sekitarnya. Sel menjadi sel kanker akibat ke- rusakan DNA pada sel yang tidak dapat diperbaiki. Sel dengan DNA yang rusak terus tumbuh dan dapat bermetastasis ke organ tubuh yang lain (American Cancer Society, 2015). Kanker pada anak dapat terjadi secara tiba-tiba tanpa gejala awal. Kanker pada anak yang paling umum adalah leukemia. Tumor 
lain seperti tumor otak, limfoma dan sarcoma jaringan lunak juga dapat terjadi pada anak. Gejala dan pengobatan kanker tergantung pada jenis kanker dan stadiumnya. Pengobatan kanker dapat dilakukan dengan operasi, radiasi dan kemoterapi (National Cancer Institute, 2009).

Insiden kanker anak di Inggris pada tahun 2009-2011 adalah 1.574 kasus baru, dan 525 anak meninggal akibat kanker. Pada tahun 2006-2010 sebanyak 82\% anak berhasil bertahan hidup selama 5 tahun atau lebih (Cancer Research UK, 2012). Menurut Riset Kesehatan Dasar (Riskesdas), tahun 2013 di Indonesia, insiden kanker pada anak usia kurang dari 1 tahun $(0,3 \%)$, usia 1-4 tahun $(0,1 \%)$, usia 5-14 tahun $(0,1 \%)$, dan usia 5-24 tahun $(0,6 \%)$. Prevalensi kanker berdasarkan jenis kelamin laki-laki $(0,6 \%)$ dan perempuan (2,2\%). Menurut National Cancer Institute (2009), jenis kanker yang paling umum terjadi pada anak-anak dan remaja adalah leukemia, tumor otak, tumor sistem saraf pusat, limfoma, rhabdomiosarkoma, neuroblastoma, tumor Wilms, osteosarkoma, dan tumor gonad germ cell.

Anak yang menderita kanker sering mengalami gangguan tidur dan kelelahan (Rosen, Shor, \& Geller, 2008). Menurut Rahmawaty, Allenidekania, dan Waluyanti, (2014) anak remaja yang menderita kanker dan menjalani pengobatan kemoterapi dapat mengalami gangguan tidur dan kelelahan yang dapat memengaruhi kualitas hidup anak. Owens, (2011) menyatakan bahwa anak dan remaja dengan kanker yang mendapatkan kemoterapi memiliki kualitas tidur yang lebih buruk dibandingkan dengan anak yang sehat. Anak dengan limfoblastik leukemia akut (LLA) $87 \%$ mengalami gangguan tidur pada fase maintenance kemoterapi. Sekitar 26-40\% anak yang mendapatkan terapi kanker mengalami nyeri sedang sampai nyeri hebat, dan anak yang mengalami nyeri menunjukkan masalah gangguan tidur (Gedaly-Duff, et al., 2006).
Kualitas tidur yang buruk dan tingginya tingkat kelelahan pada anak dan remaja selama menjalani kemoterapi dapat berakibat buruk pada penurunan daya tahan tubuh dan perkembangan kognitif anak (Vallance, Yang, Li, Crabtree, Pamela, \& Mandrell, 2011). Anak dengan kanker yang sedang menjalani kemoterapi memiliki risiko yang besar untuk mengalami insomnia dan gangguan siklus tidur-terjaga. Kecemasan dan depresi adalah respon psikologis yang dapat muncul juga pada anak yang mengalami gangguan tidur. Anak dengan nyeri kronis juga berisiko tinggi mengalami gangguan tidur berupa peningkatan durasi terbangun dari tidur pada malam hari (Bruni \& Lovelli, 2009).

Anak dengan penyakit kanker sering mengalami gangguan tidur, sehingga kuantitas dan kualitas tidur tidak terpenuhi. Anak akan melakukan adaptasi untuk menjaga keseimbangan sistem kehidupan, sehingga tercapai konservasi dan keutuhan. Model konservasi Levine berfokus pada adaptasi dan keutuhan dengan menggunakan prinsip konservasi. Model ini digunakan perawat untuk berfokus terhadap pengaruh dan tanggapan pada tingkat individu. Perawat menyelesaikan tujuan dari model ini melalui konservasi energi, konservasi integritas struktural, konservasi integritas pribadi dan konservasi integritas sosial (Levine, 1967 dalam Fawcett, 2005). Perawat dapat menggunakan keempat prinsip konservasi sebagai panduan dalam memberikan asuhan keperawatan.

\section{Metode}

Penelitian ini menggunakan desain studi kasus. Kasus yang diambil sebanyak 5 kasus. Penelitian dilakukan di ruang non infeksi anak Rumah Sakit Umum Pusat Nasional (RSUPN) Dr. Cipto Mangunkusumo Jakarta. Penelitian dilakukan pada Maret sampai dengan Mei 2015. Sampel dalam penelitian ini adalah anak yang dirawat di ruang non infeksi yang mengalami masalah gangguan tidur. Data di- 
dapatkan dari catatan medis dan keperawatan pasien serta melakukan pemeriksaan fisik dan observasi pada pasien.

\section{Hasil}

Kasus 1, anak K, perempuan, usia 4 tahun 8 bulan, masuk ruang rawat non infeksi pada tanggal 4 Oktober 2014 dengan dignosa medis Leukemia Limfolastik Akut (LLA) L3. Riwayat kesehatan sebelumnya, pasien pertama kali didiagnosis LLA pada bulan Mei 2014 berdasarkan hasil Bone Marrow Puncture (BMP). Pasien mulai kemoterapi pada tanggal 20 Juni 2014, pasien mendapatkan Dexamethason dosis tinggi $6 \mathrm{mg} / \mathrm{m}^{2}$, Metotrexat berkala $12 \mathrm{mg}$ melalui intra tecal (IT). Pada awalnya pasien dapat berjalan normal, tetapi sejak bulan Agustus 2014 pasien mulai tidak mau berjalan karena merasa nyeri pada paha dan lutut. Pasien masuk rumah sakit dengan LLA L3 post fase induksi tidak remisi.

Pengkajian tanggal 27 November 2015 menemukan data: keadaan umum pasien lemah, berat badan $16 \mathrm{~kg}$, lingkar lengan atas $14 \mathrm{~cm}$, terdapat melena dan petekie, terdapat hepatomegali, splenomegali dan terdapat fraktur oblik komplit mid diafisis femur dekstra dengan displacement fragmen distal ke anterolateral. Kesadaran pasien kompos mentis, keluarga mengatakan pasien tidak bisa tidur nyenyak, pasien selalu mengigau dan tidak bisa terlepas dari main game online dengan telepon genggam. Saat tertidur pun posisi tangan pasien memegang telepon genggam dan saat dicoba diambil pasien akan terbangun dan menangis. Durasi tidur siang tidak lebih dari 1 jam, durasi tidur malam 5 jam dengan frekuensi bangun di malam hari lebih dari 4 kali. Pasien membutuhkan waktu lebih dari 30 menit untuk dapat tertidur. Kelopak mata pasien tampak ada lingkaran hitam dan edema. Pasien tampak sangat kelelahan dan rewel, pasien hanya mau ditemani oleh ibunya dan menolak didekati oleh ayah maupun anggota keluarga yang lain.
Trophycognosis gangguan tidur diatasi dengan intervensi melakukan sleep hygiene dengan membantu anak gosok gigi sebelum tidur, perawat membacakan buku cerita, memberikan relaksasi dengan teknik nafas dalam dan bimbingan imajinasi visual, mengkondisikan kamar dan lingkungan yang tenang dan nyaman dengan mengatur suhu ruangan dan cahaya yang tidak terlalu terang, dan mengatur jadwal pemberian obat kaptopril (jam 06.00 dan 18.00) karena dapat menyebabkan insomnia pada anak. Kolaborasi dengan dokter dalam pemberian obat dilakukan untuk mengatasi nyeri. Pada hari perawatan ke-7 (tujuh) pasien mengalami perbaikan, durasi tidur siang 90 menit, tidur malam 6 jam, frekuensi bangun di malam hari kurang dari 3 kali dan anak tampak lebih segar saat bangun di pagi hari. Setelah perawatan selama 3 bulan, pada 15 Desember 2014 pasien diperbolehkan pulang, masalah gangguan tidur sudah teratasi.

Kasus 2, anak B, laki-laki, usia 4 tahun 8 bulan, dirawat dengan diagnosis medis Yolk sack tumor. Riwayat penyakit sebelumnya adalah pasien terdapat benjolan di testis kanan yang semakin membesar sejak usia 2 tahun. Keluarga tidak membawa anaknya berobat ke dokter tetapi dibawa ke pengobatan alternatif dan tidak ada perubahan karena benjolan semakin membesar. Pada bulan Desember 2014 pasien dibawa ke Rumah Sakit Umum Daerah (RSUD) Koja dan dilakukan operasi serta biopsi dengan hasil Yolk Sack Tumor. Pasien dirujuk ke RSUPN Cipto Mangunkusumo untuk kemoterapi. Pasien sudah mendapatkan kemoterapi siklus pertama pada tanggal 16 Maret 2015. Pada tanggal 26 Maret 2015 anak dirawat di ruang febril neutropenia setelah 3 hari post kemoterapi karena anak mengalami diare dengan frekuensi $14 \mathrm{x} / \mathrm{hari}$ dan demam dengan suhu $40^{\circ} \mathrm{C}$.

Pengkajian tanggal 26 Maret 2015 kondisi pasien masih lemah, kesadaran kompos mentis, frekuensi buang air besar masih lebih dari $5 \mathrm{x} /$ hari, konsistensi encer, warna feses kuning 
terang. Pasien tidak tampak tanda dehidrasi, balance cairan 12 jam positif $160 \mathrm{cc}$, berat badan $14,5 \mathrm{~kg}$, tanda-tanda vital tekanan darah $86 \mathrm{mmHg}$, nadi 130x per menit, pernafasan $27 \mathrm{x}$ per menit, suhu $37^{\circ} \mathrm{C}$, anak tampak rewel dan menangis ketakutan saat didekati perawat atau dokter. Nenek pasien mengatakan pasien tidak bisa tidur nyenyak dan sering terbangun pada malam hari, durasi tidur malam 7 jam, tidur siang sekitar 90 menit.

Trophycognosis gangguan tidur diatasi dengan intervensi melakukan komunikasi secara terapeutik, mengajak anak bermain, membacakan cerita, menjaga hubungan baik dengan orang tua, memberikan madu sebelum anak tidur, melakukan sleep hygiene, serta memberikan lingkungan yang tenang dan nyaman. Pada hari ke-7 perawatan didapatkan hasil evaluasi frekuensi bangun di malam hari 1 kali dan durasi tidur 11 jam, masalah gangguan tidur teratasi.

Kasus 3, anak C, laki-laki, usia 13 tahun 3 bulan, dibawa ke RS untuk kemoterapi fase konsolidasi protokol LLA High Risk. Riwayat kesehatan sebelumnya pada bulan Desember 2014 anak mengeluh batuk dan dibawa ke Puskesmas. Anak mendapatkan terapi Obat Anti TBC (OAT) selama 4 bulan tetapi tidak ada perbaikan. Kondisi anak semakin memburuk, kemudian anak dibawa ke RSUD Bogor dan karena mengalami anemia, anak dirujuk ke RS Cipto untuk dilakukan BMP. Hasil BMP positif LLA L1 dan anak mendapatkan kemoterapi pertama pada tanggal 16 Januari 2015.

Hasil pengkajian didapatkan pasien mengalami diare tanpa dehidrasi, balance cairan 12 jam minus $130 \mathrm{cc}$, terdapat bengkak pada pipi kiri, pasien mengeluh nyeri gigi dan gusi, dari hidung keluar cairan encer kekuningan yang berbau busuk. Selama dirawat anak mengatakan tidak bisa tidur nyenyak karena sering terbangun untuk BAK dan pasien sulit untuk tidur kembali. Durasi tidur malam 6 jam dan tidur siang 1-3 jam, pada siang hari pasien lebih banyak tidur.

Trophycognosis gangguan tidur diatasi dengan intervensi melakukan sleep hygiene, memberkan madu sebelum anak tidur, memberikan kenyamanan, mengajarkan teknik relaksasi dan berkolaborasi dengan dokter untuk mengatasi masalah nyeri. Pada hari ke- 4 perawatan hasil evaluasi frekuensi bangun di malam hari 2 kali dan durasi tidur 9 jam, gangguan tidur teratasi.

Kasus 4, anak A, perempuan, usia 11 tahun dengan diagnosis medis Rhabdomiosarcoma. Riwayat kesehatan sebelumnya sejak bulan Januari 2015 anak mengeluh gatal dan terdapat benjolan kecil di kelopak mata atas sebelah kiri. Anak dibawa ke dokter dan disangka alergi. Kondisi anak tidak menunjukkan adanya perbaikan, kemudian anak dirujuk ke RSUPN CM pada bulan April 2015 dan dilakukan biopsi. Anak didiagnosis Rhabdomiosarkoma embrional grade III. Anak mulai kemoterapi tanggal 6 Mei 2015.

Pengkajian pada tanggal 11 Mei 2015 menemukan anak mengeluh nyeri dengan skala 6 , nyeri tumpul dirasakan pada kepala bagian oksipitalis, nyeri hilang timbul, pada pemeriksaan fisik terdapat benjolan di palpebra dengan ukuran massa 7,5 cm x $6 \mathrm{~cm} \times 3,5 \mathrm{~cm}$, terdapat lesi yang bernanah di bagian atas massa dan berbau busuk. Anak mengeluh sulit untuk tidur karena menahan nyeri, posisi tidur anak duduk membungkuk, durasi tidur malam 4-5 jam dan tidur siang 1-2 jam tetapi anak merasa tidurnya tidak bisa nyenyak. Anak mendapatkan terapi MST 2x10 mg per oral (PO).

Selama perawatan Trophycognosis masalah kurang tidur dan gangguan rasa nyaman (nyeri) diatasi dengan intervensi antara lain mengajarkan pasien teknik relaksasi dan bimbingan imajinasi visual, memonitor tandatanda vital, melakukan sleep hygiene, memberikan madu sebelum anak tidur, memonitor nyeri pasien, dan berkolaborasi 
dengan dokter dalam memberikan analgesik. Setelah dilakukan asuhan keperawatan selama 3 hari, pada hari ke-4 pasien diperbolehkan pulang dan masalah gangguan tidur belum teratasi, pasien masih sulit untuk tidur karena masih merasakan nyeri. Edukasi sleep hygiene diberian sebelum pasien pulang.

Kasus 5, anak A, laki-laki, usia 4 tahun, di rawat dengan diagnosis medis LLA L3. Saat ini pasien direncanakan untuk kemoterapi siklus 1 B protokol Limfoma Burkit tahun pertama. Riwayat kesehatan sebelumnya pada bulan November 2014 anak dibawa ke RS Salak Bogor dengan keluhan tiba-tiba memar di kaki, muncul petekie, gusi berdarah dan anak sangat pucat. Pasien dirujuk ke RSCM dan dilakukan BMP dengan hasil LLA L3. Pasien mulai kemoterapi pada bulan Desember 2015 dengan protokol LLA High Risk. Setelah fase induksi selesai, protokol kemoterapi diganti dengan protokol Limfoma Burkit.

Pengkajian dilakukan pada tanggal 11 Mei 2015 dan didapatkan data pasien batuk pilek, tidak ada demam, pemeriksaan tanda-tanda vital tekanan darah $110 / 80 \mathrm{mmHg}$, nadi 125 $\mathrm{x} / \mathrm{menit}$, pernafasan $28 \mathrm{x} / \mathrm{menit}$, suhu $36,8^{\circ} \mathrm{C}$. Ibu pasien mengatakan anaknya rewel dan trauma dengan perawat atau dokter, anak sering terbangun pada malam hari, pasien mulai tidur pada pukul 18.00 dan terbangun pukul 03.00 setelah itu pasien tidak tidur lagi, tidur siang kurang dari 60 menit. Pada hari ke4 anak direncanakan untuk kemoterapi MTX IT di pagi hari, pasien diminta puasa dari malamnya, ibu pasien mengatakan tidur anaknya jadi terganggu karena anak merasa ketakutan untuk MTX IT, pasien sering terbangun dan mengigau.

Trophycognosis gangguan tidur diatasi dengan intervensi antara lain melakukan sleep hygiene, memberikan madu sebelum anak tidur dan membacakan buku cerita sebelum anak tidur, memberikan lingkungan yang nyaman dan aman. Hari ke-7 perawatan hasil evaluasi frekuensi bangun di malam hari 1 kali dan durasi tidur 11 jam, masalah gangguan pola tidur teratasi.

\section{Pembahasan}

Hasil pengkajian menunjukkan status gangguan tidur pada kelima kasus. Pengkajian gangguan tidur dilakukan dengan menggunakan instrumen Bedtime issues, Axcessive Daytime Sleepiness, Night Awakenings, Regularity and Duration of Sleep, Snoring (BEARS). Evaluasi gangguan tidur anak dilakukan pada pagi hari (jam 8 pagi) dengan wawancara orang tua atau pasien langsung. Analisis terhadap masalah gangguan tidur dilakukan dengan mengidentifikasi waktu yang dibutuhkan anak untuk bisa tertidur, jumlah terbangun pada malam hari, durasi tidur, identifikasi apakah anak sulit dibangunkan pada pagi hari dan lebih banyak tidur di siang hari serta adanya gangguan pernafasan saat anak tidur.

Pada kasus 1 (An. K, perempuan, usia 4 tahun 1 bulan) mengalami masalah gangguan tidur dengan frekuensi bangun di malam hari sebanyak 6 kali, durasi tidur 7 jam, sleep onset 40 menit. Kasus 2 (An. B, laki-laki, usia 4 tahun 7 bulan) frekuensi bangun di malam hari 3 kali, durasi tidur 9 jam, sleep onset 30 menit. Kasus 3 (An. C, laki-laki, usia 13 tahun) frekuensi bangun di malam hari $4 \mathrm{kali}$, durasi tidur 7 jam, sleep onset 35 menit. Kasus 4 (An. A, perempuan, usia 13 tahun) mengalami masalah kurang tidur akibat nyeri kronik, frekuensi bangun di malam hari 6 kali, durasi tidur 7 jam, sleep onset 35 menit. Sedangkan kasus yang ke 5 (An. AK, laki-laki, usia 4 tahun) frekuensi bangun di malam hari $3 \mathrm{kali}$, durasi tidur 9 jam, sleep onset 30 menit. Pasien yang mengalami frekuensi bangun di malam hari lebih dari 3 kali akan terlihat lebih banyak tidur di siang hari. Semua pasien dalam kasus kelolaan ini tidak mengalami gangguan pernafasan saat tidur.

Berdasarkan analisis hasil pengkajian didapatkan bahwa masalah gangguan tidur meskipun bukan menjadi masalah yang prioritas, namun 
menurut Levine masalah konservasi energi merupakan prinsip utama dalam mempertahankan adaptasi. Pada prinsip konservasi energi pemenuhan kebutuhan istirahat dan tidur memegang peranan penting dalam membantu proses adaptasi individu. Menurut Pamela, Marilyn, Rai, Zhang, Razzouk, dan McCarthy, et al., (2007) tidur memiliki fungsi sangat vital untuk konservasi energi setelah anak melakukan aktivitas sehari-hari. Tidur juga memiliki fungsi restoratif untuk anak-anak dan remaja karena memberikan periode peningkatan sintesis protein, perbaikan fungsi sel, dan pelepasan hormon pertumbuhan yang berkontribusi terhadap pembaharuan jaringan sehingga dapat membantu proses penyembuhan penyakit.

Beberapa kendala yang ditemukan saat melakukan intervensi, diantaranya adalah kondisi lingkungan yang kurang kondusif, seperti kondisi air conditioner yang tidak berfungsi dengan baik sehingga suhu kamar menjadi panas, lampu kamar yang terlalu terang dan dengan saklar paralel sehingga tidak dapat mengatur kondisi lingkungan sesuai kebutuhan pasien. Pasien yang dirawat di sebuah kamar yang berisi 6 buah tempat tidur dan hambatan dalam penerapan sleep hygiene sering terjadi akibat kondisi pasien lain yang kondisinya membutuhkan observasi ketat dan terpasang monitor. Suara nyaring dari monitor dan aktivitas perawatan pasien lain juga dapat mengganggu kenyamanan tidur pasien. Penyelesaian masalah ini dilakukan melalui jalur manajemen yaitu untuk segera memperbaiki air conditioner. Penyelesaian gangguan faktor lingkungan eksternal yang lain disiasati dengan menganjurkan anak memakai penutup mata dan telinga serta memberikan madu sebelum anak tidur untuk membantu meningkatkan kualitas tidur.

Intervensi lain yang dapat dilakukan adalah dengan mempertimbangkan komponen model Levine. Konservasi energi Levine sebagai komponen utama dan pertama tidak dapat ter- lepas dari intervensi konservasi integritas struktural, konservasi integritas personal dan konservasi integritas sosial. Kasus 1 (An. K) mengalami gangguan tidur karena anak merasa tidak nyaman dengan adanya traksi pada kaki kiri, aktivitas perawatan, dan ansietas. Kasus 2 (An. B) masalah gangguan tidur terjadi karena anak mengalami diare dan ansietas (kecemasan). Kasus 3 (An. C) gangguan tidur terjadi akibat gangguan lingkungan dan nyeri. Kasus 4 (An. A) terdapat nyeri kronik yang mengakibatkan masalah kurang tidur. Pada kasus 5 (An. AK) mengalami gangguan tidur akibat ansietas dan faktor lingkungan berupa aktivitas perawatan.

Evaluasi intervensi yang sudah dilakukan pada model Levine dengan menilai respon organismik dan menentukan apakah intervensi yang dilakukan membantu kebutuhan pasien atau tidak. Evaluasi terhadap masalah gangguan tidur dilakukan dengan mengidentifikasi waktu yang dibutuhkan anak untuk bisa tertidur, jumah terbangun pada malam hari, durasi tidur, identifikasi apakah anak sulit dibangunkan pada pagi hari dan lebih banyak tidur di siang hari serta adanya gangguan pernafasan saat anak tidur.

\section{Kesimpulan}

Anak dengan kanker dapat mengalami masalah gangguan tidur. Asuhan keperawatan dilakukan pada lima kasus pada anak yang mempunyai kanker dengan menggunakan Model Konservasi Levine. Trophycognosis yang teridentifikasi adalah gangguan tidur. Meskipun bukan masalah prioritas yang harus diselesaikan namun menurut Levin gangguan tidur adalah masalah yang harus segera ditangani karena dapat berkontribusi cukup besar terhadap kesembuhan dan hari rawat pasien. Intervensi yang sudah dilakukan seperti sleep hygiene memberikan dampak positif pada pasien sehingga dapat direkomendasikan menjadi salah satu intervensi yang harus dilakukan di ruang rawat kanker anak (NN, HR, AM). 


\section{Referensi}

Alligood, M.R., \& Tomey, A.M. (2006). Nursing theory utilization \& application (3rd Ed.). St. Louis: Mosby Elsevier.

American Academy of Sleep Medicine. (2008). Sleep Deprivation. Diperoleh dari http://www. aasmnet.org/resources/factsheets/sleepdeprivat ion.pdf

American Cancer Society. (2015). Cancer in children. Diperoleh dari http://www.cancer. org/cancer/cancerinchildren/detailedguide/canc er-in-children-cancer

Berger, A.M. (2009). Update on the state of the science: Sleep-wake disturbances in adult patients with cancer. Oncology Nursing Forum, 36 (4), 165-177. doi: 10.1188/09.ONF .E165-E177.

Cancer Research UK. (2012). Children's cancer statistic. Diperoleh dari http://www.cancer researchuk.org/health-professional/cancer-stati stics/childrens-cancers.

Davis, K.F., Parker, K.P., \& Montgomery, G.L. (2008). Sleep in Infants and Young Children: Part One: Normal Sleep. J Pediatr Health Care, 18, 1-10. Diperoleh dari http://www.me dscape.com/viewarticle/471909_5

Fawcett, J. (2005). Contemporary Nursing Knowledge: Analysis and Evaluation of Nursing Models and Theories, 2nd ed. Philadelphia: FA Davis Company.

Gedaly-Duff, Vivian, L., Kathryn, A., Nail, Lillian, M., Nicholson, S., Johnson, \& Kyle P. (2006). Pain, Sleep Disturbance, and Fatigue in Children With Leukemia and Their Parents: A Pilot Study. Oncology Nursing Forum, 33, 641-651.
Owen, J.A. (2011). Update in pediatric sleep medicine. Current Opinion in Pulmonary medicine, 17, 425-430. doi: 10.1097/mcp.0b 013e32834ba901

Pamela, H.S., Marylin, H., Rai, S.N., Zhang, L., Razzouk, B.I., McCarthy, K., et al. (2007). Nocturnal awakenings, sleep environment interruptions, and fatigue in hospitalized children with cancer. Oncology Nursing Forum, 34, 393-402. doi: 10.1188/07.ONF. 393-402

Parish, J.M. (2009). Sleep-related problems in common medical conditions. Chest, 135 (2), 563-572.

Rahmawaty, F., Allenidekania, Waluyanti., F. (2014). Sleep distubances and fatigue in adolscents with cancer receiving chemotherapy. Makara J Health Res., 18 (2).

Roger, G., \& Brand, S.R., (2011). Sleep in children with cancer. Curr Opin Pediatr, 20 (6), 676681.

Shakankiry, H.M. (2011). Sleep physiology and sleep disorders in childhood. Nature and Science of Sleep, 3, 101-114.

Stepanski, E.J., Walker, M.S., Schwartzberg, L.S., Blakely, L.J., Ong, J.C., \& Houts, A.C. (2008). The relation of trouble sleeping, depressed mood, pain, and fatigue in patients with cancer. Journal of Clinical Sleep Medicine, 5 (2), 132-136. Diperoleh dari https://www.n cbi.nlm.nih.gov/pmc/articles/PMC2670332/

Vallance, K.,Yang, J., Li, J.,McLaughlin., V., et al, . (2011). Disturbed Sleep in Pediatric Patients With Leukemia: The Potential Role of Interleukin-6 (-174GC) and Tumor Necrosis Factor (-308GA) Polymorphism. Oncology Nursing Forum, 38, 365-372. doi: 10.1188/11.ONF.E365-E372. 